\title{
Physical therapy evaluation and treatment in low back fracture: a case report
}

\author{
Avaliação e tratamento fisioterapêutico na fratura de vertebra lombar: \\ relato de caso \\ Tamiris Beppler Martins ${ }^{1}$, Géssica Maria Moreira ${ }^{1}$, Camila Fadel da Silva ${ }^{1}$, Aline Dandara Rafael' ${ }^{1}$ Larissa Sinhorim ${ }^{1}$, \\ Gilmar Moraes Santos ${ }^{1}$
}

\begin{abstract}
Introduction: falls are common in elderly and can cause fractures, with a consequent decrease in functional capacity and quality of life of these individuals. Physical therapy has fundamental role in early return of patients to their activities of daily living. Objective: evaluate the effectiveness of physical therapy on pain and functionality in elderly patients with fractures in the spine. Method: subject to 65 years of age, female, fracture history in the first lumbar vertebra. The participant was evaluated through a Physical Therapy Evaluation form, Visual Analogue Scale, Roland Morris disability questionnaire and the lumbar disability index of OSWESTRY. A treatment protocol was applied for ten sessions. Results: the results showed decreased pain and increased functionality after 10 training sessions. Conclusion: the proposal of physical therapy proved effective in gaining functionality and reducing pain.

Keywords: Low back fractures; Physical therapy; Rehabilitation.

\section{RESUMO}

Introdução: quedas são frequentes em idosos e podem acarretar fraturas, com consequente diminuição na capacidade funcional e qualidade de vida desses indivíduos. A fisioterapia apresenta papel fundamental no retorno precoce desses pacientes às suas atividades de vida diária. Objetivos: avaliar a eficácia do tratamento fisioterapêutico na dor e funcionalidade em paciente idoso com fratura na coluna. Método: sujeito com 65 anos de idade, sexo feminino, com histórico de fratura na primeira vértebra lombar. O participante foi avaliado por meio de uma ficha de Avaliação Fisioterapêutica, Escala Visual Analógica, questionário de incapacidade de Roland Morris e o índice de incapacidade lombar de OSWESTRY. Um protocolo de atendimento foi aplicado durante dez sessões. Resultados: os resultados mostraram diminuição da dor e aumento da funcionalidade após as 10 sessões de treinamento. Conclusão: a proposta de tratamento fisioterapêutico mostrou-se eficiente no ganho de funcionalidade e redução da dor.
\end{abstract}

Palavras-chave: Fratura de vértebra lombar; Fisioterapia; Reabilitação.

Corresponding author: Tamiris Beppler Martins. Rua Vidal Gregório Pereira, 363, Florianópolis (SC), Brasil. Phone: (48) $9630-4554$.
E-mail: tamirismartins@outlook.com

${ }^{1}$ Universidade do Estado de Santa Catarina (UDESC), Florianópolis (SC), Brasil.

Financial support: None.

Submission date 06 December 2015; Acceptance date 18 February 2016; Publication date 27 February 2016. 


\section{INTRODUTION}

With aging, there is a reduction of neuromotor performance, associated with reduction in number and size of muscle fibers, causing gradual loss of muscle strength and postural instability, which are associated with increase of falls in the elderly. ${ }^{(1,2)}$

Fall is an unintentional displacement of the body to a lower level of the initial position, with inability to correction in a timely manner, determined by multifactorial factors that compromise the stability. ${ }^{(3)}$

The occurrence of falls can be by extrinsic ${ }^{(4)}$ or intrinsic factors. Among the extrinsic factors are the slippery surface ${ }^{(5)}$, or arrangement of furniture in the house ${ }^{(6)}$, these are factors that best correlate with falls. ${ }^{(7)}$ The cognitive and physical state of the individual are intrinsic factors ${ }^{(4)}$ being related to the reduction of physical mobility, advanced age, when balance is impaired, muscle strength, vision, among others. ${ }^{(8)}$

Recurrent falls and fear of falling are some of the psychological factors that can lead to depression and isolation of this individual, due to the fear of being hospitalized and becoming dependent. ${ }^{(9)}$

Fractures of the spine has a prevalence of $54.4 \%$ and are one of the main consequences of falls. Thus, the physical therapy rehabilitation becomes necessary to recover the individual's functional capacity. ${ }^{(10)}$

In physical therapy intervention, therapeutic exercises plays a key role in prevention, maintenance and improvement of the functional capacity of the elderly, significantly increasing muscle strength, joint integrity and balance, ensuring autonomy and independence of the elderly. ${ }^{(11,12)}$

Some treatment protocols that aimed at the recovery of functional capacity and decreased pain are performed on a long- term. Driusso et al ${ }^{(13)}$ used a 6 - month rehabilitation program, which included stretching, walking, active exercises of upper limb, lower limb strengthening, relaxation and massage. Rennó(14) using stretching, postural exercises, walking and relaxation in a two- month protocol, observed positive effect on functionality and pain.

These authors did not include manual therapy techniques that promote plasticity of myofascial tissue in their protocols. Thus, it is believed that a treatment protocol involving manual therapy could provide faster recovery of functional capacity and reduction of pain symptoms in elderly patients with history of falls.

Given the above, the objective of this study was to evaluate the effectiveness of a physical therapy involving therapeutic exercise and manual therapy on pain and functional capacity in elderly patients with first lumbar vertebra fracture (L1) in 10 sessions.

\section{METHOD}

\section{Design}

This is a case report characterized as a descriptive study with an intentional sample. This study obtained ethical approval (number 789.272) from the Human Research Ethics Committee of Universidade do Estado de Santa Catarina.

\section{Research period and place}

This study was conducted at the Clinical School of Physiotherapy at Universidade do Estado de Santa Catarina UDESC in Florianopolis. Both evaluation and physical therapy intervention took place from March to April 2015.

\section{Data collection instruments}

Instruments used at the beginning and end of treatment were a Physical Therapy Evaluation Form, Visual Analogue Scale (VAS), Roland Morris Disability Questionnaire (RMDQ) and OSWESTRY Disability Index (ODI).

Teachers responsible for Orthopedics discipline of UDESC developed the Physical Therapy Evaluation Form. This form contained identification data, anamnesis (medical history), physical examination, goals and behaviors.

We used $\mathrm{VAS}^{(15)}$ to measure the scale of back pain in patients. This scale is graduated in ten levels, in which zero is no pain and ten is the worst pain possible. Therefore, pain can be classified in three levels: mild (zero to two), moderate (three to seven) and severe (eight to ten).

To evaluate the functionality of lumbar spine, the Roland Morris Disability Questionnaire (RMDQ) was applied, validated in the Portuguese version in 2001 by Nusbaum, et. al. ${ }^{(16)}$, which features 24 items with zero to one scores (yes or no) and total ranges from zero (suggesting no disability) to 24 (severe disability). Being applied in the evaluation and reevaluation.

For the same purpose, we applied the OSWESTRY Disability Index (ODI), which was validated in the Portuguese version in 2007 by Vigatto, et al. ${ }^{(17)}$, consisting of 10 questions with six alternatives, whose value ranges from zero to five. The first question evaluates the intensity of pain and the other nine evaluate the effect of pain on daily activities, such as personal care (dressing and bathing), lift weights, walk, when sitting, standing, sleeping, locomotion, in sex life and in social life. Total score is divided by the number of questions answered and multiplied by the number 5 . Being rated in minimal disability

(0 - 20\%), moderate ( $21-40 \%)$, severe (41 - 60\%), patient wo presents invalid (61-80\%) and individual who is bedridden (81-100\%). It is also applied in the evaluation and reevaluation.

\section{Case report}

Female patient, 65 years old, with clinical diagnosis of lumbar vertebra (L1) fracture. The etiology was trauma due to falling from a chair in which the column has contact with the ground. After the trauma, the patient remained for three months with a brace to stabilize the vertebra, and only after this, the individual began physical therapy.

\section{Procedures}

The subject was informed about the study and then signed a free and informed consent form.

Ten physiotherapy sessions were conducted twice a week for five weeks, lasting 50 minutes each. A single therapist performed the intervention and physical therapy evaluation. 
In the first session was held the physiotherapy assessment, which included anamnesis (medical history), physical examination, application of VAS, Roland Morris Disability Questionnaire (RMDQ) and OSWESTRY Disability Index (ODI).

Muscle strength tests were performed using Kendall scale, which is graded 0- $5^{(17)}$, in hip flexor, extensor, adductor and abductor muscles, in knee flexor and extensor muscles, and in

ankle dorsi- and plantar- flexor muscles. Muscle strength scale can be found in Table 1.

The established treatment plan aimed to reduce pain in the lumbosacral region, improve body awareness, improve mobility of the lumbar spine, practice static and dynamic balance, adjust gait pattern, provide better stability of the lumbar spine, and increase muscle strength.

To cater to these objectives, the treatment protocol consisted of manual therapy and kinesiotherapy, being:

1. shallow and deeper sliding body, pompage and myofascial release in prevertebral, lumbar quadrate, iliolumbar and sacroiliac ligaments, piriformis, diaphragm, abdominal and iliopsoas;

2. abdominal and paravertebral strengthening on the mat, and it was also experienced in Swiss ball, but the patient did not adapt, it were performed 8 repetitions of each exercise in 3 sets;

3. gait phases training in the hallway, ramp and stairs;

4. static and dynamic balance training evolving from bipedal to unipedal;

5. bed mobility training, passing from sitting to standing.

One of the attendances was conducted in the therapeutic pool, in order to reduce pain and bring a sense of relaxation to the patient. This specific attendance contained gait training, trunk stretching, prevertebral strengthening with spaghetti float, anterior and posterior pelvic tilt exercise, step ascend and descend and at the end we used the Bad Ragaz Ring Method (BRRM), for relaxation.

Table 1. Muscular strength pre and post- intervention physiotherapy.

\begin{tabular}{lccccc}
\hline \multirow{2}{*}{ Muscles } & \multicolumn{2}{c}{ PRÉ } & & \multicolumn{2}{c}{ PÓST } \\
\cline { 5 - 6 } & Right & Left & Right & Left \\
\hline Hip flexor muscle & 4 & 4 & 4 & 4 \\
Hip extensor muscle & 1 & 1 & 3 & 3 \\
Hip abductor muscle & 3 & 3 & 3 & 4 \\
Hip adductor muscle & 3 & 2 & 3 & 3 \\
Knee flexor muscle & 3 & 4 & 3 & 4 \\
Knee extensor muscle & 4 & 4 & 4 & 4 \\
Ankle dorsi flexor muscle & 3 & 3 & 3 & 3 \\
Ankle plantar flexor muscle & 3 & 4 & 3 & 4 \\
\hline
\end{tabular}

\section{Data analysis}

Data analysis was descriptive.

\section{RESULTS}

In visual analogue scale, the patient said she was in pain 10 (maximum) in appraisal day, and reported pain 3 (moderate) in the last day.

Figure 1 shows the functional capacity assessed by Roland Morris Disability Questionnaire (RMDQ).

It can be seen that functionality improved from the first to the last session. Initially it was classified in severe disability (24 points) and in mild disability (10 points) at the end.

Figure 2 shows the disabling low back pain by OSWESTRY Disability Index (ODI).

It can be observed improvement in functional capacity of the lumbar region of the subject. The score in the first session was 23 points, accounting for $46 \%$ of the score in severe disability, and the last session was 5 points, representing only $11 \%$ of the score in minimal disability.

\section{Functional Disability}

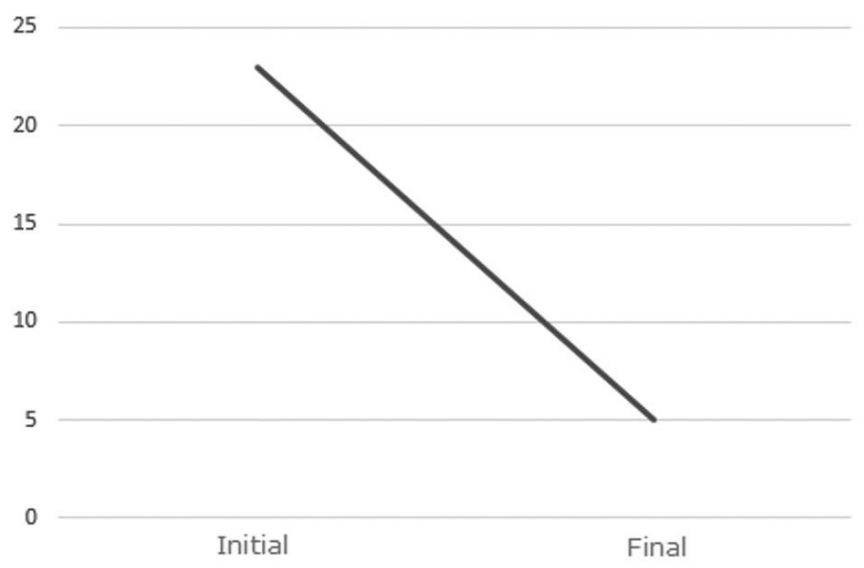

Figure 1. Assessment of functional capacity by RMDQ.

\section{Functional Disability}

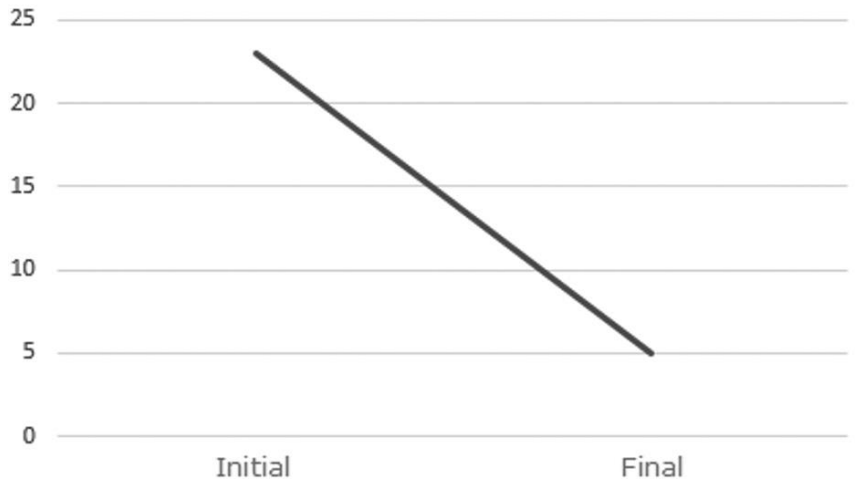

Figure 2. Assessment of functional disabling low back pain by ODI. 
Results for muscle strength are shown in Table 1.

There was an increase in the bilateral hip extensor strength, hip abductor and adductor muscle of left lower limb and all other previously tested muscles was maintained the same force at the end of the protocol.

\section{DISCUSSION}

The aim of this study was to evaluate the effectiveness of physical therapy on pain and functional capacity in elderly patients with L1 fracture.

The results showed reduced pain and increased functional capacity after physical therapy protocol of 10 sessions.

The decreased of pain from 10 to $3(70 \%)$ suggests that the application of manual therapy techniques could accelerate the pain reduction in short time. This result is higher than in ROSAS and SATO (2007) study ${ }^{(18)}$ that through a physical therapy program with sessions 8 of manual therapy and Mackenzie Method observed reduction of $47 \%$ in VAS. ${ }^{(18)}$ It is possible that manual therapy has balanced the bodily tension by disruption of tissue adhesion, thus reducing the pain symptoms. ${ }^{(19)}$

Faced with the decrease in the intensity of pain, the gain in functional capacity becomes more efficient, favoring the elderly independence in their activities of daily living. DRIUSSO et al. ${ }^{(13)}$ and RENNÓ(14), after performing a physical activity program for six months and four months respectively, observed an improvement in the personal care, performance on home activities and work, giving greater independence to the elderly. The results of this study also show improvement in functional capacity with consequent improvement in activities of daily living, however the recovery obtained was faster, in a month and a week (10 attendances) where the subject of the study was severe inability to minimal disability or Light.

The gain of functional capacity is possibly related to increased muscle strength. Katch ${ }^{(21)}$ submitted a healthy men group, aged between 60 to 72 years, to a strength training program over 12 weeks and found that muscle strength was increasing progressively at about $5 \%$, and increase muscle volume, each session. The results of this study also show increased muscle strength by Kendall scale, although this have occurred in five weeks.

When involve elderly, the gain of functional capacity and independence in rehabilitation protocols should be objectified early, since elderly people already have decreased mobility and flexibility, and when suffer fractures, especially in the spine, these issues become even more evident, reducing their functional independence and quality of life. ${ }^{(22)}$

The physiotherapy treatment should always seek for the patient quality life. In this study, the aquatic environment has become a pleasant environment in which it was observed potentiation of treatment, although it was performed only once. Positive results with the aquatic environment improves the quality of life have been found in other studies. ${ }^{(23-27)}$
Finally, it is believed that the combination of manual therapy with kinesitherapy this protocol (one month and one week), provided rapid relief of pain which enabled an early gain of independence and functionality when compared with other studies that require 4 and 6 months to achieve similar results.

\section{CONCLUSION}

The proposed treatment protocol for this case, proved to be effective in reducing the pain symptoms and increased independence and functional capacity over a period of a month and a half.

\section{AUTHOR'S CONTRIBUTION}

TBM and GMM: Design and development (provided the idea for research or article and created the hypothesis); GMS and LS: Supervision (responsible for organizing and execution of the project and writing of the manuscript); GMM: Collection and processing of data (responsible for experiments, patients and organization of data); TBM, GMS, LS: Analysis / interpretation (responsible for statistical analysis, evaluation and presentation of results); CFS: Literature survey (participated in the bibliographical research and articles survey); TBM, CFS, GMM, ADR: Wording (responsible for writing a substantive part of the manuscript); TBM, CFS, GMS, GMS, LS, ADR: Critical revision (responsible for reviewing the intellectual content of the manuscript before final submission).

\section{COMPETING INTERESTS}

The authors declare that they have no conflicts of interest in the research.

\section{REFERENCES}

1. Mazzeo RS, et. al. American College of Sports Medicine position standard. Exercise and Physical Activity for older adults. Med. Sci. Sports Exerc. 1998,30:992- 1008.

2. Baumgartner RN, et. al. Epidemiology of Sarcopenia among the ilderly in New Mexico. Am. J. Epidemiol. 1998;147:755- 63.

3. Pereira SRM, et. al. Quedas em Idosos. Sociedade Brasileira de Geriatria e Gerontologia; 2001.

4. Close JC, et. al. What is the role os falls? Best Pract. Res. Clin. Rheumatol. 2005;19 (6):913- 35 .

5. Lopes $\mathrm{MCL}$, et. al. Fatores desencadeantes de quedas no domicílio em uma comunidade de idosos. Cogitare Enferm. 2007;12(4):472- 7.

6. Findorff MJ, et. al. Circumstances and consequences of falls in community -dwelling older women. J. Womens Health (Larchmt). 2007,16(10):143746.

7. Ganança FF, et. al. Circunstâncias e consequências de quedas em idosos com vestibulopatia crônica. Ver. Bras. Otorrinolaringol. 2006,72(3):38893.

8. Sambrook PN, et. al. Influence of fall related factors and boné strength on fracture risk in the frail elderly. Osteoporos Int. 2007;18(5):603-10.

9. Fletcher PC, Hirdes JP. Restriction in activity associated with fear of falling among community - based seniors using home care services. Age Ageing. 2007;33(3):273-0.

10. Kock A, Graells XS, Zaninelli, EM. Epidemiologia de fraturas da coluna de acordo com o mecanismo de trauma: análise de 502 casos. Coluna/ Columna. 2007;6(1):18-23.

11. Nnodim JO, Alexander NB. Assessing falls in older adults: a comprehensive fall evaluation to reduce fall risk in older adults. Geriatrics 2005;60(10):24- 8.

12. Chanler J, Studensk S. Exercícios. In: Duthie EH, Katz PR. Geriatria prática. 3.ed. Rio de Janeiro: Revinter;2002.125- 39. 
13. Driusso P. Efeito de um programa de atividade física na qualidade de vida de mulheres com osteoporose. Dissertação de mestrado, Departamento de fisioterapia da Universidade Federal de São Carlos, De- Fisio, UFScar, 2000.

14. Rennó ACM. Efeitos de um programa de exercícios físicos no grau de cifose torácica, na função pulmonar e na qualidade de vida de mulheres com osteoporose. Dissertação de mestrado, Departamento de fisioterapia da Universidade Federal de São Carlos, De- Fisio, UFScar, 2003.

15. Hospital Israelita Albert Einstein. Gerenciamento da dor na SBIBHAR. 2010.

16. Nusbaum L, et. al. Translation, adaptation and validation of the Roland - Morris questionnaire - Brazil Roland - Morris. Braz J Med Biol Res. 2001:34(2):203-210

17. Vigatto R, Alexandre NM, Correa Filho HR. Development of a Brazilian Portuguese version of the Oswetry Disability Index: cross- cultural adaptation, reliability, and validity. Spine (Phila Pa 1976). 2007;32(4):481- 6.

18. Kendall HO, Kendall FP, Wadsworth GE. Músculos: provas e funções. $2^{\text {a }}$ ed. Barcelona: JIMS; 1979.

19. O'Sullivan SB, Schmitz TJ. Fisioterapia: avaliação e tratamento. 5a ed. Manole: São Paulo; 2010
20. Sato MM, Rosas RF. Tratamento fisioterapêutico com método Mackenzie na dor lombar. Revista Unisul - Fisioterapia, 2007.

21. Katch FI, Mcardle WD. Nutrição, exercício e saúde. 4ạ e.d. Rio de Janeiro: Editora MEDSI, p. 513 - 525, 1996

22. Rose J, Gamble JG. Enfermagem em terapêutico oncológica. 3ạ e.d. São Paulo: Atheneu, 2005.

23. Fleck SJ, Kraemer WJ. Fundamentos do treinamento de força muscular. 2a e.d. Porto Alegre: Artmed, 1999, p. 200- 10.

24. Resende SM, Rassi CM, Viana FP. Efeitos da hidroterapia na recuperação do equilíbrio e na prevenção de quedas em idosas. Revista Brasileira de Fisioterapia, São Carlos. 2008;12(1):57- 63.

25. Geytenbeek J. Evidence for efetive hydrotherapy. Physiotherapy. 2002;88(9):514-529.

26. Candeloro JM, Caromano FA. Efeito de um programa de hidroterapia na flexibilidade e na força muscular de idosas. Revista Brasileira de Fisioterapia, 2007;11(4):303-309.

27. Caromano FA. Fundamentos da hidroterapia para idosos. Arquivos de Ciências da Saúde da UNIPAR, 2001;5(2):187-195. 